\title{
Politics of Culture and Communication and the Islamic Republic of Iran
}

\author{
Mehdi Semati \\ Northern Illinois University, DeKalb, IL, USA \\ msemati@niu.edu
}

The Islamic Republic of Iran remains a foreign policy 'challenge' to the prevailing international order, though it might be more accurate to call it international disorder. The disorder came into sharp view recently when Mohammad Javad Zarif, Iranian foreign minister, accompanied Federica Mogherini, the High Representative of the European Union for Foreign Affairs and Security Policy, as she unveiled elaborate plans to undermine the administration of Donald Trump and salvage the 'Iran Deal'. The plan involved a 'special vehicle' conceived to circumvent the new and renewed us financial sanctions against Iran and companies that seek to do business there. As if to make the disorder even more pronounced, France, Germany, Britain, Russia and China announced their support for the plan in a joint statement. ${ }^{1}$ The gap that separates the European Union and the United States regarding Iran is as much about American belligerence and Trump's shenanigans in the Middle East as it is about the Islamic Republic of Iran's survival instinct and its strategic and geopolitical steps and missteps. Regardless of how one characterizes the internal and external factors at play, the Islamic Republic of Iran remains very much a 'problem' on the global stage.

That gap between the European Union and the United States is also fueled by the internal contradictions of the discursive position Iran occupies as an 'Islamic nation' and a 'trouble spot' in the 'Middle East' in Western geopolitical and popular imaginaries. These contradictions include an insistence on the backward character of Iranian rulers (and Iran as a nation of 'fundamentalists') while warning about Iran's capabilities of enriching uranium, nuclear technology and long-range ballistic missiles. In other words, we are warned about a

1 For details on the status of the Iran deal in this regard, see Hirsh (2018).

2 The designation of the region is Eurocentric; it assumes a center in Europe, with the 'Middle East' being east of that center. For more on geography and empire, see Said (1994). 
backward nation with fanatical rulers who have nevertheless managed to build technologically advanced (and lethal) weaponry, with nuclear technology as well. More important, the Western imaginary is confounded by contradictions: Iran is a morbid object of geopolitical discourse and it is the place from which remarkable cultural forms and productions continue to emerge.

The contributors to this special issue of the Middle East Journal of Culture and Communication engage with these cultural forms and institutions and the sociopolitical contexts of their production, circulation, reception and operation. These cultural forms include popular music, theater, poetry, museums, cinema and art. The contributors address the politics of the Western discourses on Iran as they discuss these cultural forms at the intersection of political, social and cultural registers and their co-constitutive relationships.

In her contribution to this collection of essays, Theresa Steward examines the fraught relationship between Iranian musicians and the Western media and their audiences. For example, once moving beyond the novelty of rock or pop music in Iran, Western observers often look for signs of 'resistance' and 'revolutionary' culture of artist seeking to escape the repression of the ayatollahs. In this scenario, Iranian musicians are engaged in a constant battle for survival against a loathsome state in a closed and oppressive social space. This reductive tendency, which collapses all aspects of culture into a 'political' dimension, is a feature of much writing on culture in Iran. ${ }^{3}$ The reality is far more interesting and complicated than such depictions or descriptions allow. As Steward shows, musicians are aware of this Western appetite for 'resistance' narratives, and some, with a Western audience in mind, use it to their strategic advantage. In her essay, Steward focuses on Bahman Ghobadi's No One Knows About Persian Cats (2009) (a film about the 'underground' music scene in Iran), to demonstrate how Iranian musicians occupy a multi-faceted and complex position that goes well beyond alleged perpetual 'protest' and 'defiance.'

Erum Naqvi's contribution addresses the thriving theater scene in Iran. It might be accurate to say that Iran has never had such a dynamic theater scene, from mainstream and well-known Iranian and foreign plays, to experimental and musical theaters. Arguably, theater in Iran has never been as popular as it

3 For an elaboration on the politicization of culture in Iran in Western works, especially in relationship to popular music, see Nooshin (2017) and Semati (2017).

4 There is a shared perception among young cinephiles in Iran that Ghobadi crafted his films to appeal to the sensibility of Western audiences. While I do not judge the veracity of such a claim, I would suggest that Iranian audiences are quite sophisticated with regard to their own self-perception and their position on the global stage. 
is today; many shows in Tehran and other major cities are regularly sold out. In addition, newer genres, such as 'horror' (vahshat), are refashioning this ancient art form. ${ }^{5}$ These are remarkable developments that repudiate ignorant comments about Iranian cultural and social space made by those who wish to vilify the Islamic Republic. More importantly, the developments are noteworthy, as they shed light on the dynamism of the cultural sphere, in spite of the state.

This dynamism can be observed, for example, in the way art collectives run by younger artists are reimagining and rearticulating historical art forms (e.g., ruhowzi) that were deemed too 'un-Islamic' to be performed in public spaces after the revolution in 1979. Naqvi's essay presents this re-articulation as a vibrant cultural re-production of the boundaries of various genres, which are constantly renegotiated, reimagined and playfully reworked. These re-imaginings are not attempts at resistance but are reformulations of the classical canons of theater in Iran, with inflections of joy, aspirations, fears and anxieties that are relevant in the contemporary conjuncture. In this playful rearticulation, where the past is restated in the aesthetic grammar of today, we find the pleasures of the popular.

Shareah Taleghani's essay addresses the poetry of Solmaz Sharif, an IranianAmerican poet whose work has been celebrated for her experimentation with form and uncompromising critique of 'war on terror' and her denunciation of militarism and war. Taleghani's focus on Sharif's poetry in Look (2016) is partly informed by the post-colonial literature on translation theory (with which she examines Sharif's work as a subversive act of 'translation' as cultural practice), and as an assessment of the efficacy of intralingual modes of translation.

Sharif's poems render the English language unfamiliar and foreignize it; the audience's complicity in the sanitizing effects of militarized language is unsettled. Taleghani explores how, by reappropriating military discourse, Sharif's poetry is a form of 'resistant domestication' that reflects the experience of diaspora, exile, immigration, transnational identity, belonging and estrangement, all shaped by her own experience as a member of the Iranian-American diasporic community.

In her contribution to this collection, Anna Vanzan addresses the topic of museums in Iran. As a product of the Enlightenment era, Vanzan identifies how museums are instruments to rationalize human affairs and their place in the cosmological order. The efforts by the Iranian state to build museums is not unique; many states have done so. By focusing on the Holy Defense Museum

5 I would like to thank Soroush Shaker and his theater groupmates for invitations to plays in Tehran during my visits, and for engaging conversations about the state of theater in Iran. 
and the Martyrs' Museum, Vanzan shows the ideological interests of the state in aestheticizing the war via religious iconography and symbolism and mobilizing collective memory as projects of political identity and popular mobilization. I would argue that the Iranian state's recent interest in building lavish museums is no longer an attempt to 'stage a revolution' (Chelkowski and Dabashi 1999), but more an effort to revive it, and resuscitate its affective power and ideological allure, at times also injecting nationalistic mythologies (i.e., elements of pre-Islamic and Persian identities) into it. In fact, such attempts by the state reflect its anxieties about its perceived failure to maintain a revolutionary state and to acknowledge tacitly the unfulfilled promises of a forty-year-old revolution. Today, many cultural forms, implicitly and sometimes explicitly contain elements of 'popular history' that entertain narratives about such promises and about life before the 1979 revolution.

Niloo Sarabi's contribution offers a rereading of Marzieh Meshkini's Roozi ke zan shodam (The day I became a woman), a critically acclaimed film that takes up the question of gender and women's position in the Islamic Republic. This film was released nearly two decades ago and is clearly a testament to the ongoing and relentless assertion of the agency of Iranian women; furthermore, it illustrates that popular culture in the Islamic Republic has long been a contentious cite of struggle over the meaning of gender, womanhood and women's role in society. As Hamid Naficy argued, with regard to Iranian cinema, 'a unique and unexpected achievement of this cinema has been the significant and signifying role of women both behind and in front of the camera, leading to "women's cinema"' (Naficy 2003:138). One of the paradoxes of 'Islamicization' of Iranian society has been the opening of various cultural industries to women, who, in turn, have challenged the terms of their representation. ${ }^{6}$ As Sarabi argues, the visual codes of representation of women in this context have entailed both limitations and opportunities with regard to the portrayal of women in the cinema and their presence in the film industry. Moreover, her discussion acknowledges the longstanding internal debates in Iran on gender and gender roles. Sarabi reflects on the ways in which Meshkini's visual aesthetics, the formal characteristics of her film, and its other narrative properties contribute to debates in Iran on the veil, gender norms, social mobility and women's pleasure.

Alice Bombardier's essay addresses painting and art in Iran. Nothing seems to embody the contradictions of the Islamic Republic like the art scene in Iran.

6 For more on the development of cinema and the structural conditions of this development (i.e., 'Islamicization') that have led to the powerful presence of women in the film industry, see Naficy $(1991 ; 1994)$. 
Just as the Us sanctions were renewed and the Iranian currency is in decline, art auctions at posh hotel ballrooms in North Tehran have brought large sums for various works of arts, especially paintings. A recent headline states, 'Iran art auction rakes in millions amid pressure over sanctions' (Najib 2019). At an auction in Tehran recently, a journalist told me that art journalists in Iran believe that collecting expensive art is a good way for billionaires to 'park' cash. More ominously, and perhaps cynically, another journalist joked that buying expensive art is one of the best methods of laundering money. Thus, the renewed interest in the art scene in Iran is propelled by its connection to the global art market and by the participation of contemporary Iranian artists in the global art scene. The interest is also driven by recent scholarship on Iranian art, to which Bombardier has contributed. ${ }^{7}$ In some ways, the renewed interest in painting might also reflect a desire to rediscover the suppressed history of painting as a cultural form, suppressed by a history born out of authoritarian state (under the Pahlavi monarchy), geopolitical developments (e.g., the red scare of the Cold War era) and post-revolution domestic politics (a religious state and its cultural revolution).

Bombardier's research is distinctive, in the sense that her work is grounded in a historical framework that is cognizant of both continuity and breaks in the ongoing fate of painting. In her contribution to this collection, Bombardier traces the origins of 'New Painting', a term she prefers over the Persian renditions of 'contemporary painting' (naqqashi-i muasir) or 'modern painting' (naqqashi-i modern). The artists of 'new painting' were innovative in many respects. They introduced new methods, forms, and, perhaps more important, 'social innovations through new channels of collective creation' (e.g., associations, galleries/clubs, conferences, journals). Yet, for all the innovations of these pioneers introduced, their history and contributions have been forgotten, or even erased, from most accounts of painting in Iran. Bombardier offers explanations grounded in an analysis of the political and social contexts of the era in which these pioneers made their contribution and of the subsequent contexts of the reception of their work. Her essay is an important step in recovering their legacy.

The articles in this collection, individually and collectively, challenge the prevailing views regarding Iran and cultural production and practices in the Islamic Republic of Iran. The contributors question simplistic explanations about Iran and the Islamic Republic, a feature of far too much commentary about Middle Eastern societies and cultures. The analyses of these authors

7 See Bombardier (2017), Grigor (2014) and Keshmirshekan (2014). 
demonstrate that the realities of Iran and its people are far more complicated, interesting and dynamic than the prevailing discourses about Iran would suggest. It might be safe to say, Iran is no exception in being misunderstood as a country in the Middle East, an 'imaginative geography,' to use Edward Said's (1979) language.

\section{References}

Bombardier, Alice (2017). Les pionniers de la Nouvelle peinture en Iran. QEuvres méconnues, activités novatrices et scandales au tournant des années 1940. Bern: Peter Lang.

Chelkowski, Peter and Hamid Dabashi (1999). Staging a Revolution: The Art of Persuasion in the Islamic Republic of Iran. New York: New York University Press.

Grigor, Talinn (2014). Contemporary Iranian Art: From the Street to the Studio. London: Reaktion Books.

Hirsh, Michael (2018). Is Iran Deal Finally Dead? Foreign Policy. Accessed 18 Jan. 2019, online: https://foreignpolicy.com/2018/og/25/iran-nuclear-deal-last-stand/, 25 September 2018.

Keshmirshekan, Hamid (2014). Contemporary Iranian Art: New Perspectives. London: Saqi Books.

Naficy, Hamid (1991). Women and the Semiotics of Veiling and Vision in Cinema. American Journal of Semiotics 8 (1-2): 47-64.

Naficy, Hamid (1994). Veiled Visions/Powerful Presences: Women in Postrevolutionary Iranian Cinema. In Mahnaz Afkhami and Erika Friedl (eds.), In the Eye of the Storm: Women in Postrevolutionary Iran, pp. 131-15o. London: I.B. Tauris.

Naficy, Hamid (2003). Poetics and Politics of Veil, Voice, and Vision in Iranian Postrevolutionary Cinema. In David A. Bailey and Gilane Tawadros (eds.), Veil:Veiling, Representation and Contemporary Art, pp. 136-159. London: Institute of International Visual Arts with Modern Art Oxford.

Najib, Mohammad Ali (2019). Iran Art Auction Rakes in Millions amid Pressure over Sanctions. Aljazeera. Accessed 18 January 2019 online: https://www.aljazeera.com/ indepth/inpictures/iran-art-auction-rakes-millions-pressure-sanctions-19011217355 9995.html, 14 January 2019.

Nooshin, Laudan (2017). Whose Liberation? Iranian Popular Music and the Fetishization of Resistance. Popular Communication: The International Journal of Media and Culture 15 (3): 163-191.

Said, Edward (1979). Orientalism. New York: Vintage Books.

Said, Edward (1994). Culture and Imperialism. New York: Vintage Books.

Semati, Mehdi (2017). Sounds Like Iran: On Popular Music of Iran. Popular Communication: The International Journal of Media and Culture 15 (3): 155-162. 